\title{
PLANNING FOR RESPONSE TO BIOTERRORISM
}

\author{
Donald F. Hagen \\ Executive Vice Chancellor \\ University of Kansas Medical Center
}

From 1981-1984, I headed the Contingency Planning Division for the Navy's Bureau of Medicine and Surgery and planned medical treatment for situations such as conventional warfare, ships at sea, and studied medical response alternatives to nuclear, chemical and biological warfare. It was our job to evaluate risks and plan medical support alternatives. We worked inside a wellstructured and controlled environment, and used modeling to develop our plans. This was easy compared to what we have now. I'm no longer in the navy and found myself outside the box on September 11. It was frightening. Our first concern was the safety of our faculty and students. Our people at the University of Kansas Medical Center (KUMC) work globally. I was pleased that the schools could give me a complete list of staff and students' locations within half an hour. On a personal level, the attack at the Pentagon was a shock. The plane hit the area that included where my office had been located in 1985. We were all shocked by events.

Our first response at KUMC was to take care of our people. We have students from many countries, and we care about them, but in retrospect we made some mistakes. We asked our chaplains to put together an interfaith service. It turned out to be a Christian interdenominational service, but the people attending were Jewish, Muslim, Sikh, and Christian. Some were offended. We have learned that in these types of situations, innocent people can inadvertently become victimized by situations they would not have experienced before. A landlord evicted one of our Muslim medical students from her apartment. One of our professors is of the Sikh and wears a turban every day. He is often taken aside and questioned at airports as he travels about the nation - this causes a great deal of stress upon him and upon people of his faith.

Before September $11^{\text {th }}$, we thought chemical, biological and nuclear warfare was unlikely in the continental United States. Now we know this is not true, and that America must take a new look at its public health system. There is much to do. Our detection systems are inadequate. We must decide whether or not to keep viruses for vaccines. In the early 1980's we thought the only reason to keep the smallpox vaccine was to counter the military threat of the Cold War. This is a major issue for the country - smallpox is a viable agent for biological warfare. We do not seem to be prepared. And no one is standing up saying that they'll work on the problem. There is no clear message.

America needs to change - we know this. It is important to understand the threat. In a nuclear war, medical providers would respond immediately. In a 
chemical attack, the effect is immediate and devastating, and medical treatment is limited. Bioterrorism is different - there is a long delayed reaction time. I'm concerned that no single agency has the answers. The federal government should do the threat assessment and work on response alternatives. Someone has to be in charge of command and control. At the state level, the Governor's office would likely define our roles in a disaster. Regionally, our responsibilities could include coordinating toxicology labs and other functions that require interstate coordination.

I remember when I came to Kansas seven years ago, I asked - who is in charge of the health of Kansans? It is hard to find an answer. The Kansas Health Foundation has been bringing people together with common interests to talk about public health. We strongly believe that communities need to be better educated. And we must get to know each other. It doesn't matter what kind of plan you have, if people don't know each other and have a sense of operating together, it won't work in an emergency. Communication is critical.

What is the role of the university? At KUMC, we have been working with the Kansas Department of Health and Environment, with our own infectious disease specialists, and with the KU School of Continuing Education to provide distance education conferences that reach health care people in their communities. We are talking with them about their role in diagnosing a bioterrorist action - for example, what is smallpox? We must be prepared to receive casualties. Most hospitals don't want to take smallpox cases because they might contaminate their entire facility. We must decide where to take people who are infected. And how do we deal with the dead? Our morgue at the Medical Center can only accommodate six people.

We've had concerns about the preservation of the food supply. We had a conference a couple of years ago on agri-medicine. It was sponsored by lowa State University, but included representatives from all of the universities represented here today. We discussed the gamut of issues regarding agriculture and health and it was very successful. In Kansas, Dodge City, Garden City and Liberal rely on a migrant work force that moves back and forth between Kansas and Mexico. I worry about an outbreak of measles or tuberculosis in that population, and am not convinced that these issues are all appropriately addressed. So what happens if migrant workers are exposed to biological agents?

We must keep current anti-bioterrorism initiatives going and maintain visibility. KU's Continuing Education School develops programs for firefighters, police and community leaders. We work with the Kansas Health Foundation, the Academy of Family Physicians and others. We have been preparing grant applications to build better communications between public health professionals and practicing doctors in Kansas. If we do not work together, the public will be 
sent back and forth between the public health department and their family doctors in an endless loop as they look for answers about anthrax, for example.

We must ask ourselves, what will we do when the phone rings tomorrow? Will we call the Kansas Department of Health and Environment? Should we call the local public health department or the medical society? Should the public go to the emergency room? One reliable source of emergency information is the web site of the Center for Disease Control.

Terrorism is caused by something and we should address that cause. In my opinion we need a Marshall Plan for the Middle East. Together, we must find homes for the homeless, educate the poorest of the poor and feed the hungry. How is our foreign policy interpreted around the world? We are the dominant power - let's not become the Roman Empire of 2002 debating in the Senate while the terrorists are invading. We must move forward. We need an early defense system, but we must not forget to address the causes of terrorism and work together to create a more peaceful world. 